\title{
Organ Measurements Assessment Test Code
}

National Cancer Institute

\section{Source}

National Cancer Institute. Organ Measurements Assessment Test Code. NCI Thesaurus. Code C119901.

A character or string that represents the short code name of the organ measurements. 